DOI: $10.18522 / 2073-6606-2016-14-3-101-111$

\title{
EVALUATION OF CLUSTER EFFICIENCY MEASUREMENT TOOL
}

\section{Kristina RAZMINIENE், Doctoral Student, \\ Vilnius Gediminas Technical University, Expert, VšI Entrepreneurship and Sustainability Center, Vilnius, Lithuania, e-mail: kristina.razminiene@vgtu.lt; \\ Manuela TVARONAVIČIENĖ, PhD, Professor, Vilnius Gediminas Technical University, Vilnius, Lithuania, e-mail:manuela.tvaronaviciene@vgtu.lt;}

Vaida ZEMLICKIENÉ, $\mathrm{PhD}$, Researcher,

Vilnius Gediminas Technical University, Vilnius, Lithuania, e-mail: vaida.zemlickiene@vgtu.lt

This study aims at verifying the validity of cluster efficiency measurement tool. In previous study benchmarking was employed (Tvaronavičienè et al., 2015) to compare the performance of participating clusters which would enable to improve their results by getting the information about their strengths and weaknesses over other clusters. A further comparison of data of four participating clusters was pursued while paying attention on the importance of three groups of criteria, which are activity, resources and processes, giving them different prominence. Two more values were added to previous study, one indicating the results when all three groups of indicators get the same weights and the other shows their efficiency when processes get the major part and the other two groups are equally relevant. There was a significant change in results when these conditions were applied showing the importance of literature and case analysis. Further analysis is needed to verify the validity of a cluster efficiency measurement tool as there were no previous attempts to assess cluster efficiency through benchmarking clusters performing in Lithuania. This study may give controversial results as the prominence to each group of criteria is given regarding to literature analysis as well as author's personal opinion. Limited number of clusters may influence the choice of the alternatively best ratio of three criteria characterizing the performance of clusters.

Keywords: cluster efficiency; benchmarking; case analysis; cluster performance

JEL classifications: $R 1$

(C) К.Разминене, М. Тваронавичене, В. Землицкене, 2016 


\title{
ОЦЕНКА ИНСТРУМЕНТОВ ИЗМЕРЕНИЯ КААСТЕРНОЙ ЭФФЕКТИВНОСТИ
}

\author{
К. РАЗМИНЕНЕ, \\ докторант, \\ Вильнюсский технический университет им. Гедиминаса, \\ эксперт Центра предпринимательства и устойчивого развития, \\ Вильнюс, Литва, \\ e-mail: kristina.razminiene@vgtu.lt; \\ M. TВAРОНАВИЧЕНE, \\ $\mathrm{PhD}$, профессор, \\ Вильнюсский технический университет им. Гедиминаса, \\ Вильнюс, Литва, \\ e-mail:manuela.tvaronaviciene@vgtu.lt; \\ В. ЗЕМЛИЦКЕНЕ, \\ $\mathrm{PhD}$, исследователь, \\ Вильнюсский технический университет им. Гедиминаса, \\ Вильнюс, Литва, \\ e-mail: vaida.zemlickiene@vgtu.lt
}

\begin{abstract}
Данное исследование направлено на верификацию валидности инструмента измерения кластерной эффективности. В предыдущей работе для сравнения результатов функционирования кластеров использовался бенчмаркинг (Tvaronavičienè et al., 2015). Данный способ позволяет улучшить результаты посредством получения информации о сильных и слабых сторонах относительно других кластеров. Дальнейшее сравнение данных по четырем рассматриваемым кластерам предполагает учет важности трех групп критериев: активность, ресурсы и процессы - рассматриваемых в контексте их различной значимости. По сравнению с предыдущим исследованием, были добавлены еще две величины, одна из которых отражает результаты при неизменных весах для всех трех групп критериев, а другая - характеризует их эффективность в ситуации, когда наибольший вес имеет критерий «процессы», а две других группы критериев имеют одинаковые веса. При применении данных условий было выявлено значимое различие в результатах, которое показало важность анализа литературы и изучения конкретных случаев. Верификация валидности инструмента измерения кластерной эффективности требует проведения дальнейших исследований, поскольку прежде не предпринималось попыток оценить эффективность кластера посредством бенчмаркинга кластеров, функционирующих в Литве. Результаты данного исследования могут оказаться противоречивы, поскольку в соответствии с научной литературой, а также в зависимости от авторской позиции, степень значимости каждой группы критериев может различаться. Ограниченное количество кластеров может оказывать влияние на альтернативный выбор наилучшего соотношения трех критериев, характеризующего эффективность функционирования кластеров.
\end{abstract}

Ключевые слова: эффективность кластера; бенчмаркинг; анализ кейса; функционирование кластера 


\section{Introduction}

According to Karaev et al (2007), clusters are recognizable as an important instrument for improving SMEs productivity, innovativeness and overall competitiveness through overcoming their size limitations. Although there are many various studies conducted in different countries but a common understanding of the cluster concept has not been generally accepted yet. One of the most prominent authorities in the field is M. Porter (1990), who claims that national clusters are formed by firms and industries linked through vertical (buyer/supplier) and/or horizontal (common customers, technology, etc.) relationships with the main players located in a single nation/state. Later this definition was supplemented by Porter (1998), who added institutions (formal organizations) such as universities. The ability for a country to form an industrial cluster can be related to its international competitive advantage. Reduced input costs of the manufacturers, development of common suppliers, training of professional labor and a technical knowledge spillover effect can be achieved through the formation of clustering $(H s u, 2014)$. The effectiveness of a cluster is supposed to be increased by facilitating the transmission of knowledge and the development of institutions, which can be achieved through geographical proximity. Another important feature that is stressed by Porter (1998) is encouraging of innovation through enhanced division of labor among companies with physical proximity among numerous competing producers.

Questions related to performance of clusters are widely discussed in scientific literature: researchers discuss such aspects as measuring of innovations (Rezk at al. 2015), approaches and methods of cluster analysis (Tvaronavičiene at al. 2015a; 2015b), technology transfer processes and driving forces (Tvaronavičiené, Černevičiūtè 2015; Ignatavičius et al.); composition and governance specifics (Branten, Purju 2015; Fuschi, Tvaronavičienè 2016; Bistrova et al. 2014; Lace et al. 2015; Mentelet al. 2016; Raudeliūnienè et al. 2016); participation of start-ups (Laužikas et al. 2015; Tvaronavičienè 2016). Hence, spectrum of questions related to clustering phenomena is wide; efficiency of functioning issues, as it was mentioned above, is still under discussion.

This study aims at verifying the validity of cluster efficiency measurement tool. In previous study benchmarking was employed to compare the performance of participating clusters which would enable to improve their results by getting the information about their strengths and weaknesses over other clusters. You can find the "The Cluster Efficiency Study through Benchmarking" in journal Enterpreneurship and Sustainability Issues.The mentioned study was carried out in order to compare the most successful, in a certain extent, clusters in Lithuania. Benchmarking approach was employed as the most precise technique of data analysis in given conditions. There were several methods employed in a study, such as an interview for the initial stage of data collection, questionnaire survey as well as multi-criteria analysis in later stages and benchmarking for the final stage of the study as to generalize the results. The research has shown that multi-criteria and benchmarking methods are helpful in determining cluster performance. There might be some inaccuracies regarding the results as there were several questions with information not available for the cluster managers. A great number of elements included in the questionnaire survey may have lead to some discrepancy. Benchmarking can help companies in cluster to evaluate their performance in comparison to others and seek for better results. The most successful clusters in Lithuania were studied to be a role model. Benchmarking is a practice which can help clusters to measure their performance as there is no systematic evaluation of cluster excellence in Lithuania (also see Tvaronavičiene et al., 2015).The continuation of the previous study and verification of its results would help companies in using their competitive advantage which is created by co-operation. A further comparison of data of four participating clusters was pursued while paying attention on the importance of three groups of criteria, which are activity, resources and processes, giving them different prominence. The question is how 
each of three groups of criteria resemble the superiority over others, how they determine the performance of the clusters and what prominence should be given to each of them to make the cluster efficiency measurement tool to be effective. Two hypotheses were reviewed in the study:

H1. Three groups of cluster efficiency measurements, which are resources, processes and activities, should have different weights for clusters show better results in specific fields.

H2. Clusters from various areas should be applied the same evaluation system with different indexes.

The verification of the cluster efficiency measurement tool through giving more prominence to one of three groups of criteria serves as a purpose of this study. The data collected in the previous study is further exploited for it is appropriate and represents the four most successful clusters in Lithuania. Further analysis is needed to verify the validity of a cluster efficiency measurement tool as there were no previous attempts to assess cluster efficiency through benchmarking clusters performing in Lithuania. This study may give controversial results as the prominence to each group of criteria is given regarding to literature analyses as well as author's personal opinion. Limited number of clusters may influence the choice of the alternatively best ratio of three criteria characterizing the performance of clusters.

The study contains a description of four clusters that are participating in the benchmarking activity through submitting information about their performance and evaluating the indicators according to their importance. The choice of clusters was previously determined by identifying seven successfully performing clusters in Lithuania, four of which accepted the invitation to participate in a study where their performance was evaluated through benchmarking. At this stage further comparison follows by giving prominence to one of three groups of indicators to see how such change can influence the results and which ratio should be applied to make a cluster efficiency measurement tool effective.

The article consists of 5 sections. Section 1 gives the introduction to the theme that is analyzed. Section 2 describes the research design and the method of data collection and all the previous steps that were made before in this study. Section 3 presents some descriptive statistics on the clusters that were taken for analysis. Section 4 illustrates the results of the study which aims at cluster efficiency measurement. Finally, Section 5 incorporates the conclusive remark and observations.

\section{Data and methodology}

Evaluation of cluster efficiency tool is continuing the previous study, which revealed significant results and requires further research. There were several stages of data collection followed to get all the necessary data. This study is supplemented by other methods of research which lead to relevant observations.

The multi-criteria SAW method was applied to process the results in the previous study as it is the oldest, most widely known, practically used method and normalized values of the evaluation SAW criterion help visually determine the differences between the alternatives compared (Podvezko, 2011). There were 44 indicators submitted for experts' evaluation. Minding the quantity of the indicators and the uncertainty of the rating to be eligible, the indicators were split into groups. Naturally, three groups were separated at the beginning, which are resources, processes and activities. Later, the resources were determined by one group of eight indicators, processes were split into two groups, ten indicators in each and activities were also split into two groups with eight indicators in each. The rating was simplified by forming five groups where the number of indicators varied from eight to ten. Such division enabled the experts to mind all the indicators in each group and make a valid evaluation. 
Previously, the performance of the clusters was evaluated by summing up the three groups of measurements, which are resources, activity and processes, or in other words, giving the same weight to each of the groups. Later analysis proved that every single group should have different weights for the clusters show exclusive results in two groups and one is not dominated by any of the clusters. Literature analysis should help in determining the rankings form each group of the indicators. Managers of the clusters cannot participate further as experts as they are not able to refer to cluster literature and analyze which of the features determined by scholars are characteristic to the groups of indicators.

Literature analysis revealed the most important factors that are emphasized by scholars when cluster notion is defined. The importance of vertical (buyer/supplier) and/or horizontal (common customers, technology, etc.) relationships (Porter, 1990; OECD, 2001; Expósito-Langaet al 2015), reduced input costs of the manufacturers, development of common suppliers, training of professional labor (Expósito-Langa et al, 2015; De Felice, 2014) and a technical knowledge spillover effect (Hsu, 2014; Akoorie, 2011), transmission of knowledge (Akoorie, 2011; OECD, 2001; Expósito-Langaet al, 2015, De Felice, 2014), development of institutions, innovation, (OECD, 2001; De Felice, 2014), division of labor (Porter, 1998; De Felice, 2014), political initiatives (OECD, 2001) is mentioned in the works of scholars suggesting the direction which should be followed in giving more prominence to one of the cluster efficiency measurement indicators.

Case analysis served in data analysis as four clusters were described, data on their performance were collected and evaluated. Four clusters from two sectors, services and industry, situated in Lithuania, were participating in the study. This kind of methodology enabled to compare the change in value of cluster efficiency after the weights of cluster efficiency measurement tool were adjusted.

To sum up, this study was carried out in continuation to previous research. Questionnaire survey and multi-criteria analysis method were applied to collect and analyze data. Case analysis was applied to reveal four clusters participating in the research and to discuss their performance through comparing clusters in different sectors. Literature analysis enabled to determine the most prominent group of indicators which was used to adjust the weights in further analysis. The results were observed, compared and hypotheses were approved according to findings discovered after correcting the cluster efficiency tool.

\section{Descriptive statistics}

In the previous study, seven clusters were identified as successful as they satisfy these requirements: a cluster has been operating for longer than two years, receives funding either from EU funds or private institutions and the results of cluster activity are satisfactory. The benchmarking involves four clusters in Lithuania that were characterized as being successful and well managed as only four clusters out of seven accepted the invitation to participate in the study, which is organized in order to create a tool to measure cluster performance in Lithuania through benchmarking. Namely, the clusters are Wellness Cluster iVita, Vilnius Film Cluster, Baltic Automotive Components Cluster (BACC) and Laser and Engineering Technologies Cluster (LITEK) (Table 1).

Vilnius Film Cluster and Wellness Cluster iVita specialize in services, changing client's physical or mental qualities while Laser and Engineering Technologies Cluster (LITEK) and Baltic Automotive Components Cluster (BACC) belong to industry sector. Most of the clusters were established in 2011 while BACC was established in 2013 being the youngest of the participating clusters. The number of companies in participating clusters varies from 11 to 22. The qualification enables to make a comparison of these clusters by grouping them according to the sector that they belong to two groups, which generally are services and industry. 
Seven successful clusters in Lithuania

\begin{tabular}{|c|c|c|c|c|}
\hline Cluster & $\begin{array}{c}\text { Establishment } \\
\text { year }\end{array}$ & $\begin{array}{c}\text { Number of } \\
\text { members }\end{array}$ & Specialization & Sector \\
\hline $\begin{array}{l}\text { Vilnius Film } \\
\text { Cluster }\end{array}$ & 2011 & 22 & Cinema and advertizing & $\begin{array}{l}\text { Services, changing cli- } \\
\text { ent's physical or men- } \\
\text { tal qualities }\end{array}$ \\
\hline $\begin{array}{l}\text { Wellness } \\
\text { ClusteriVita }\end{array}$ & 2011 & 11 & Health promotion & $\begin{array}{l}\text { Services, changing cli- } \\
\text { ent's physical or men- } \\
\text { tal qualities }\end{array}$ \\
\hline $\begin{array}{l}\text { Laser and } \\
\text { Engineering } \\
\text { Technologies } \\
\text { Cluster (LITEK) }\end{array}$ & 2011 & 13 & $\begin{array}{l}\text { Lasers and laser com- } \\
\text { ponents }\end{array}$ & Electronics industry \\
\hline $\begin{array}{l}\text { Baltic Automo- } \\
\text { tive Components } \\
\text { Cluster (BACC) } \\
\end{array}$ & 2013 & 17 & $\begin{array}{l}\text { Engineering industry } \\
\text { (manufacturing of ma- } \\
\text { chinery and devices) }\end{array}$ & $\begin{array}{l}\text { Metal machinery and } \\
\text { equipment manufac- } \\
\text { turing industry }\end{array}$ \\
\hline $\begin{array}{l}\text { Smart Technology } \\
\text { Cluster }\end{array}$ & 2011 & 11 & $\begin{array}{l}\text { Energy construction; } \\
\text { information technology } \\
\text { and communications }\end{array}$ & Information services \\
\hline $\begin{array}{l}\text { Photovoltaic } \\
\text { Technology } \\
\text { Cluster }\end{array}$ & 2008 & 29 & $\begin{array}{l}\text { Electronics; machinery } \\
\text { and devices }\end{array}$ & Electronics industry \\
\hline $\begin{array}{l}\text { Užupis Creative } \\
\text { Cluster }\end{array}$ & 2010 & 9 & $\begin{array}{l}\text { Information and com- } \\
\text { munication technolo- } \\
\text { gies; creative industries }\end{array}$ & $\begin{array}{l}\text { Services, changing cli- } \\
\text { ent's physical or men- } \\
\text { tal qualities }\end{array}$ \\
\hline
\end{tabular}

Wellness Cluster iVita introduces high quality and high value added wellness products and services that can improve human security, add efficiency to their activities, contribute to prevention and public education and promote healthy lifestyle habits. Besides strengthening the competitiveness of the cluster organizations in the domestic and export markets Wellness Cluster iVita also promote the latest and most effective production and management technologies, business and science cooperation in research and development activities, as well as youth entrepreneurship and public awareness of wellness. Today wellness cluster iVita connects 13 strong and high competence Lithuanian innovative organizations that have long term business experience and high management and technical potential that puts a strong base for rich business oriented activities towards higher competitiveness and further expansion.

Wellness Cluster iVita strive to provide long-term competitive advantage of cluster members, which operate in the same common wellness area value chain by selecting appropriate strategic tools. Wellness cluster iVita strategy includes desire to create innovative wellness products and services that improve the users safety and efficiency, promote prevention and provide added value that is clearly perceived by consumers (retrieved from the iVita website).

Vilnius Film Cluster offers a broad range of film and TV production and rental services at truly competitive prices in Northern and Eastern Europe. Vilnius Film Cluster is an alliance of leading film and TV production and production services companies. The diversity in Cluster's members' expertise enables to provide the client with full world-class service for any stage of production. Vilnius Film Cluster is proud of its professional and experienced crews and remarkable credits. It offers its newly-built soundstage with a full equipment list. As an alliance Vilnius Film Cluster established in 2011. It is implementing projects partly financed by European Union Funds via LBSA, Lithuanian business support agency, 
subordinated by Ministry of Economy of the Republic of Lithuania. Vilnius Film Cluster unites 21 leading audiovisual company and one of the largest universities in Lithuania (retrieved from the Vilnius Film Cluster website).

Baltic Automotive Component Cluster (BACC) is a public entity driven cluster, which was established in 2013. Today it consists of 18 members - 15 automotive companies, 2 education institutions (Kaunas University of Technology and Kaunas School of Mechanical Engineering) and Kèdainiai Free Economy Zone. The main number of cluster members are located in Lithuania as convenient geographical location in terms of transit between Europe and Russia. General cluster members annual turnover of 2014 amounted to 227 million EUR, the general number of employees - more than 2200. Cluster activities are aimed at supporting and strengthening the competence of partner companies along the entire value added chain (retrieved from the BACC website).

Laser \& Engineering Technologies cluster LITEK started a dozen years ago, when the laser system manufacturers in collaboration with the scientific institutions began to create unique products. Today LITEK - the structure that connects twelve companies and organizations operating in the laser and associated engineering technologies carrying out joint projects. Currently, members of LITEK are JSC Arginta, JSC Arginta Engineering, JSC Eksma, Elas, Ltd, JSC Ekspla, Public entity Science and Technology Park of Institute of Physics (Cluster Coordinator), Center for Physical Sciences and Technology, Public entity Intechcentras, JSC Optida, JSC Optolita, JSC Optonas, JSC Progressive Business Solutions. General annual turnover of LITEK companies are over 35 million Eur and they have more than 490 employees.

Mission of the cluster - active, dynamic and productive cooperation between companies, research establishments and universities, other national and international clusters, integrated science, education and business centers (valleys), and technology platforms in the field of research and innovations. Cooperation, promoting innovation of laser and engineering technology, transfer of the most recent knowledge about science and technology from academic level to business, productivity of the sector and improvement of competitiveness.

Overall goal of the cluster - to create the dynamic center of action, which would have a fully integrated chain of researchers, suppliers, manufacturers and retailers and, which would improve the international competitiveness of laser and laser-related engineering technologies as well as the knowledge and wealth of individual members.

LITEK is currently implementing 2 projects, partly covered by the funds of The European Regional Development Fund Economic Growth Operational Programme. The project applicant is cluster coordinator Public entity "Science and Technology Park of Institute of Physics"(retrieved from the LITEK website).

\section{Cluster efficiency measurement}

The questionnaire survey which was submitted in clusters, asked to evaluate the indicators in different ways. The resources were measured in units or Euros as the question was to give exact numbers of resources that were adapted in the cluster. The same situation was with processes as clusters needed to provide information about expenses, change in a number of different indicators, exact numbers of indicators. The situation was different with activities as clusters were asked to evaluate given indicators by rating them from 1 to 10 according to the performance of the cluster.

To sum up, all of three groups contain features that are characterized by scholars in their works as seen from a literature analysis (Table 2) (also see Tvaronavičienè et al., 2015). This allows distinguishing the most important features that show cluster efficiency, which are innovative, knowledge sharing, common distribution channels, qualified human resources, initiatives. All these features are most comprehensively reflected in processes and activities, although activities do not reveal definitive figures, they show more personal opinion than numbers in processes. Hence, processes must get more prominence in counting the cluster efficiency. 


\section{Indicators of cluster efficiency}

\begin{tabular}{|c|c|c|}
\hline \multirow{8}{*}{$\left|\begin{array}{l}\tilde{d} \\
0 \\
\vdots \\
0 \\
\mathscr{\Xi} \\
\approx\end{array}\right|$} & Number of cluster coordinating members & \multirow{2}{*}{\begin{tabular}{|l} 
Common supply and order scheme \\
Common distribution channels
\end{tabular}} \\
\hline & $\begin{array}{l}\text { Number of cluster members - companies, R\&D } \\
\text { subjects, supporting organizations }\end{array}$ & \\
\hline & Number of R\&D personnel & $\begin{array}{l}\text { Common cluster members' tenders for } \\
\text { external clients }\end{array}$ \\
\hline & $\begin{array}{l}\text { University graduates working at cluster compa- } \\
\text { nies }\end{array}$ & $\begin{array}{l}\text { Exchange of common market informa- } \\
\text { tion between cluster members }\end{array}$ \\
\hline & Common cluster projects in two years & Cluster advertisement (leaflets, media) \\
\hline & $\begin{array}{l}\text { Financed common cluster projects in two years } \\
\text { with cluster initiatives co-financing }\end{array}$ & $\begin{array}{l}\text { Common participation in exhibitions } \\
\text { and fairs }\end{array}$ \\
\hline & $\begin{array}{l}\text { External financing for cluster initiatives in two } \\
\text { years }\end{array}$ & Lobbying \\
\hline & $\begin{array}{l}\text { Total sum of cluster members' investments for } \\
\text { cluster initiatives in two years }\end{array}$ & Common internet site \\
\hline \multirow{16}{*}{\begin{tabular}{|l} 
\\
\\
\\
\\
\\
0 \\
0 \\
0 \\
0 \\
0 \\
0 \\
0 \\
2
\end{tabular}} & $\begin{array}{l}\text { Increase of cluster members' employees in two } \\
\text { years }\end{array}$ & $\begin{array}{l}\text { Visual identification (common logo, } \\
\text { brand) }\end{array}$ \\
\hline & $\begin{array}{l}\text { Number of internal cluster training participants } \\
\text { in two years }\end{array}$ & $\begin{array}{l}\text { Contacts and image of cluster in mass } \\
\text { media }\end{array}$ \\
\hline & $\begin{array}{l}\text { Number of cluster organized common training } \\
\text { in two years }\end{array}$ & Regular meetings of cluster members \\
\hline & $\begin{array}{l}\text { Number of qualification upgraded employees in } \\
\text { two years }\end{array}$ & Cluster integration events \\
\hline & $\begin{array}{l}\text { Increase of direct employment in cluster inno- } \\
\text { vative activities }\end{array}$ & Common communication platform \\
\hline & $\begin{array}{l}\text { Part of R\&D expenses in common expenses in } \\
\text { two years }\end{array}$ & $\begin{array}{l}\text { Common cluster publications (buck- } \\
\text { lets, newsletters, etc.) }\end{array}$ \\
\hline & $\begin{array}{l}\text { Number of common submitted/funded EU SF } \\
\text { projects in two years }\end{array}$ & $\begin{array}{l}\text { Co-operation while creating new } \\
\text { products or technologies }\end{array}$ \\
\hline & $\begin{array}{l}\text { Number of common international R\&D projects, } \\
\text { funded not from EU SF, in two years }\end{array}$ & $\begin{array}{l}\text { Co-operation while creating innova- } \\
\text { tions (organizational, marketing, etc.) }\end{array}$ \\
\hline & $\begin{array}{l}\text { Products/goods of cluster, sold in internal mar- } \\
\text { ket }\end{array}$ & ences, internships \\
\hline & $\begin{array}{l}\text { Products/goods of cluster, sold in external } \\
\text { market }\end{array}$ & Common data base \\
\hline & New cluster members in two years & $\begin{array}{l}\text { Informal sharing of knowledge and } \\
\text { experience }\end{array}$ \\
\hline & Start-up in cluster & Transference of technologies \\
\hline & $\begin{array}{l}\text { Foreign markets where members of cluster } \\
\text { works }\end{array}$ & \\
\hline & Part of export in total cluster sales & \\
\hline & $\begin{array}{l}\text { Number of official co-operation agreements } \\
\text { with foreign entities }\end{array}$ & \\
\hline & $\begin{array}{l}\text { Participation in international exhibitions and } \\
\text { sales offices in two years }\end{array}$ & \\
\hline
\end{tabular}


LITEK was identified as the most efficient cluster during the previous study when all three groups of indicators were added without giving them weights. Resources dominated for this cluster. Second place was allocated to Wellness Cluster iVita which was seen as superior in area of activities. Vilnius Film Cluster was third with the best results in processes. The last one was BACC, which stayed behind in all groups of indicators (Table 3).

Table 3

Evaluation of clusters' performance

\begin{tabular}{|l|c|c|c|c|}
\cline { 2 - 5 } \multicolumn{1}{c|}{} & iVita & Vilnius Film Cluster & BACC & LITEK \\
\hline Resources & 0,196 & 0,182 & 0,084 & 0,427 \\
\hline Activity & 0,331 & 0,198 & 0,251 & 0,217 \\
\hline Processes & 0,268 & $\mathbf{0 , 3 8 2}$ & 0,034 & 0,250 \\
\hline Total & 0,795 & 0,762 & 0,69 & $\mathbf{0 , 8 9 4}$ \\
\hline Total1 & $\mathbf{0 , 2 6 2}$ & 0,252 & 0,122 & $\mathbf{0 , 2 9 5}$ \\
\hline Total2 & $\mathbf{0 , 2 6 7}$ & $\mathbf{0 , 3 2 4}$ & 0,074 & 0,271 \\
\hline
\end{tabular}

Later, two more values were added. Total 1 illustrates the change in the result when all three groups of indicators get the same weight. It does not change the distribution of allocated places according to cluster efficiency, but it allows making a comparison of how giving prominence to one group can influence the results. Total 2 reveals a completely different scenario. Here weights are given according to the findings that processes should get more prominence in comparison to resources and activities. Hence, processes got the greater part, which is 0,7 while resources and activities share the smaller pot equally, 0,15 for each. Positions change as the most efficient cluster becomes Vilnius Film Cluster, which was third in the first case. Vilnius Film Cluster has the weightiest positive change in value as it was detected in the previous study that it is superior in processes. The value of Wellness Cluster iVita has a slight positive change and it falls down to the third place. Accordingly, LITEK falls from the first to the second place as the value changed negatively, although not significantly. The last stays BACC, which has also experienced the most significant negative change in value. The change in weights illustrates how it can influence the distribution of clusters.

The hypothesis $\mathbf{H 1}$ can be confirmed, as a literature analysis showed that processes should get more prominence, although in further analysis equal weights were ascribed to resources and activities. These two groups seem to be equally significant as resources present definitive figures, while activities render important features, although the rating imparts personal opinion rather than facts. Moreover, the most significant change in value was noticed with two clusters which present better results with different groups of indicators. On the other hand, the value of one of the clusters did not change significantly after adjusting weights as it shows good performance in all the groups of indicators. The weakest cluster show even lower results, confirming that processes play an important role in determining the efficiency of clusters.

There are two groups of clusters separated according to the sector that they belong to. Wellness Cluster iVita and Vilnius Film Cluster belongs to services while BACC and LITEK belong to industry. Adjusting weights regarding literature analysis have changed the values for both groups. Although the distribution of places according to cluster efficiency has changed significantly, there is a noticeable tendency in value change. Clusters that belong to services experienced positive change in value after the weights were adjusted and processes gained more prominence while industry clusters were affected contrary, as they experienced a negative change in the same conditions. This observation approves that $\mathbf{H} \mathbf{2}$ is true to some extent. Further analysis should be carried out with more 
clusters of different sectors to leave this hypothesis unambiguous as in this case it is complicated to detect the proportion that would suit each sector perfectly with such a limited number of clusters participating in a survey.

\section{Conclusions}

The cluster efficiency measurement tool is the main interest in this study, as the research was carried out aiming to verify the validity of this tool through literature analysis and case study. Previous study, which included benchmarking as a method to create a cluster efficiency measurement tool was further developed and supported. Four clusters were described as participants of the case study, belonging to different sectors: services and industry. Literature analysis showed that cluster efficiency is best determined by three groups of indicators, which are processes, activities and resources, but the processes should get more prominence in further analysis as it reflects the most important features of cluster performance through definitive figures. Two more values were added to previous studies, one indicating the results when all three groups of indicators get the same weights and the other shows their efficiency when processes get the major part and the other two groups are equally relevant. In the second case, the results were influenced significantly by changing the results. It is important to note that cluster, which was the last in the first case reached even lower results after giving more prominence to processes proving the importance of adjusting weights regarding to literature analysis. Moreover, clusters that belong to services experienced positive change in value while industry clusters showed a negative change in value when the weights were adjusted to support processes.

The cluster efficiency measurement tool is ready to be used in order to see how successful performance of a cluster is through benchmarking and applying formulas described in a study. This tool allows not only to measure efficiency in comparison to other clusters, but also to give valuable observation of how the performance of a cluster can be improved regarding different indicators that are included in the questionnaire survey. Analytic approach is needed to interpret the results and give reasonable recommendations.

The study needs to be continued as case analysis should be applied for more clusters in different locations and sectors. Further study would allow making rational conclusions in forming the proportion of weights given to activities, processes and resources, which would reflect the performance of clusters in the most effective way. Moreover, this study does not conclude with the proportion of how clusters in different sectors should be evaluated. Findings suggest that there is a tendency to accentuate different groups of indicators for various sectors by giving each of them more or less prominence but the limited number of clusters restrain from the specific rating system.

\section{ЛИTEPATУPA / REFERENCES}

About LITEK (2015). Retrieved from the LITEK website (http://www.litek.lt/naujienos. php?pg=news).

About us (2015). Retrieved from the BACC website (http://www.bacc.lt/).

About us (2015). Retrieved from the iVita website (http://www.i-vita.lt/en.html).

About Vilnius Film Cluster (2015). Retrieved from the Vilnius Film Cluster website (http://filmcluster.eu/).

Akoorie M.E.M. (2011). A challenge to Marshallian orthodoxy on industrial clustering // Journal of Management History, 17(4), pp. 451-470.

Bistrova J., Lace N. and Tvaronavičiene M. (2014). Corporate governance as a crucial factor in achieving sustainable corporate performance // Journal of systemics, cybernetics and informatics, 12(3), pp. 82-90.

Branten E. and Purju A. (2015). Cooperation projects between university and companies: process of formation and objectives of the stakeholders // Entrepreneurship and Sustainability Issues, 3(2), pp. 149-156. 
Expósito-Langa M., Tomás-Miquel J.V. and Molina-Morales F.X. (2015). Innovation in clusters: exploration capacity, networking intensity and external resources // Journal of Organizational Change Management, 28(1), pp. 26-42.

Felice A. (2014). Measuring the social capabilities and the implication on innovation: Evidence from a special industrial cluster // Journal of Economic Studies, 41(6), pp. 907-928.

Fuschi D.L. and Tvaronavičienè M. (2016). A network based business partnership model for SMEs management // Entrepreneurship and sustainability issues, 3(3), pp. 282-289.

Hsu M., Lai Y. and Lin F. (2014). The impact of industrial clusters on human resource and firms performance // Journal of Modelling in Management, 9(2), pp. 141-159.

Ignatavičius R., Tvaronavičienè M. and Piccinetti L. (2015). Sustainable development through technology transfer networks: case of Lithuania // Journal of Security and Sustainability Issues, 4(3), pp. 261-267.

Karaev A., Lenny Koh S.C. and Szamosi L.S. (2007). The cluster approach and SME competitiveness: a review // Journal of Manufacturing Technology Management, 18(7), pp. 818-835.

Lace N., Buldakova N. and Rumbinaite G. (2015). Organizational creativity as a driving force for company's innovative development // Entrepreneurship and Sustainability Issues, 3(2), pp. 137-148.

Laužikas M., Tindale H., Bilota A. and Bielousovaitè D. (2015). Contributions of sustainable start-up ecosystem to dynamics of start-up companies: the case of Lithuania // Entrepreneurship and Sustainability Issues, 3(1), pp. 8-24.

Mentel G., Szetela B. and Tvaronavičienè M. (2016).Qualifications of managers vs. effectiveness of investment funds in Poland // Economics \& sociology: journal of scientific papers, 9(2), pp. 126-137.

OECD (2001). Innovative Clusters.Drivers of National Innovative Systems, Enterprise, Industry and Services. Paris: OECD Publications.

Podvezko V. (2011). The comparative analysis of MCDA methods SAW and COPRAS // Inzinerine Ekonomika-Engineering Economics, 22(2), pp. 134-146.

Porter M. (1990). The Competitive Advantage of Nations.New York: The Free Press.

Porter M. (1998). Clusters and the new economy of competition // Harvard Business Review, 6(6), pp.77-91.

Raudeliūnienè J., Stadnik B. and Kindarytè $R$. (2016). Knowledge appliance process: theoretical and practical evaluation aspects // Entrepreneurship and Sustainability Issues, 3(4), pp. 368-379.

Rezk M.R.A., Ibrahim H.H., Tvaronavičienè M., Sakr M.M. and Piccinetti L. (2015). Measuring of innovation activities in Egypt: the case of industry // Entrepreneurship and sustainability issues, 3(1), pp. 47-55.

Tvaronavičienè $M$. (2016). Start-ups across the EU: if particular tendencies could be traced // Entrepreneurship and sustainability issues, 3(3), pp. 290-298.

Tvaronavičienè $M$. and Černevičiūtè J. (2015). Technology transfer phenomenon and its impact on sustainable development // Journal of Security and Sustainability Issues, 5(1), pp. 87-97.

Tvaronavičienè M., Razminiene K. and Piccinetti L. (2015a). Cluster efficiency study through benchmarking // Enterpreneurship and Sustainability Issues, 3(2), pp. 120-127.

Tvaronavičienè M., Razminienè K. and Piccinetti L. (2015b). Aproaches towards cluster analysis // Economics \& sociology: journal of scientific papers, 8(1), pp. 19-27. 